\title{
Penerapan Metode Partisipatorik Dalam Pembelajaran Bahasa Indonesia Siswa Kelas Vi Sdn 146 Asaan Kabupaten Enrekang
}

\author{
Abdul Muis \\ Sekolah Dasar Negeri 146 Asaan, Kabupaten Enrekang, Indonesia \\ Email : mmaspul@gmail.com
}

\begin{abstract}
ABSTRAK
Penelitian ini bertujuan mendeskripsikan penerapan metode partisipatorik dalam pembelajaran Bahasa Indonesia siswa kelas VI Sekolah Dasar Negeri 146 Asaan Kabupaten Enrekang. Jenis penelitian ini adalah Penelitian Tindakan Kelas. Penelitian ini dilaksanakan dalam 2 siklus yang terdiri dari empat tahapan, yaitu perencanaan, tindakan, observasi dan refleksi. Pengumpulan data dilakukan dengan cara observasi dan refleksi setiap siklus pembelajaran. Hasil penelitian menunjukkan bahwa penerapan metode partisipatorik terhadap pembelajaran Bahasa Indonesia siswa kelas VI Sekolah Dasar Negeri 146 Asaan Kabupaten Enrekang terbukti signifikan dalam meningkatkan aktivitas siswa dalam pembelajaran. Hal ini dibuktikan dengan pastisipasi siswa dalam pembelajaran. Dengan penerapan metode partisipatorik, siswa menjadi aktif dalam merencanakan, melaksanakan dan menilai pembelajaran.
\end{abstract}

Kata Kunci : Metode Partisipatorik, Pembelajaran Bahasa Indonesia, Penelitian Tindakan Kelas

\begin{abstract}
This study aims to describe the application of Participatory Method in Indonesian language learning for Grade VI students of SDN 146 Asaan, Enrekang Regency. The type of research is Classroom Action Research. This research was conducted in 2 cycles consisting of four stages, namely planning, action, observation and reflection. Data collection was done by observation and reflection in each learning cycle. The results of the study showed that the application of Participatory Method in Indonesian language learning for Grade VI students of the SDN 146 Asaan Enrekang Regency proved significant in increasing student activity in learning. This is proven by students' participation in learning. By applying Participatory Method, the students become active in planning, implementing and evaluating learning.
\end{abstract}

Keywords : Participatory Method; Indonesian Language Learning; Classroom Action Research 


\section{PENDAHULUAN}

Guru memegang peranan penting dalam proses pembelajaran. Guru harus memiliki kompetensi yang dapat mengaktifkan siswa. Akan tetapi, pembelajaran selama ini masih didominasi oleh peran guru. Akibatnya siswa menjadi pasif dan hanya berharap suapan dari guru. Hal ini menyebabkan siswa kurang mendapat kesempatan untuk mengeluarkan ide-ide sehingga kurang terjadi interaksi di antara siswa dalam proses pembelajaran (Hamalik, 2002:11).

Pembelajaran akan signifikan apabila guru dapat menciptakan kondisi belajar yang dapat membangun keaktifan siswa. Ada banyak metode yang dapat mengaktifkan siswa. Salah satu diantaranya adalah metode partisipatorik. Metode partisipatorik merupakan metode yang lebih mengaktifkan siswa dalam pembelajaran. Guru hanya sebagai fasilitator sedangkan siswalah yang berpartisipasi penuh dalam pembelajaran.

Menurut Sujana (2000:154), metode partisipatorik dapat diartikan sebagai upaya pendidik untuk mengikutsertakan peserta didik dalam kegiatan pembelajaran. Kegiatan pembelajaran dengan penerapan metode partisipatorik mengandung arti ikut sertanya peserta didik dalam program pembelajaran. Keikutsertaan peserta didik itu diwujudkan dalam tiga tahapan kegiatan pembelajaran yaitu perencanaan program (program planning), pelaksanaan (program implementation) dan penilaian (program evaluation) kegiatan pembelajaran.

Partisipasi peserta didik dalam tiga tahapan kegiatan itu pada hakekatnya merupakan kegiatan pembelajaran dalam makna yang wajar dan mempunyai pengaruh positif bagi peserta didik. Pengaaruh partisipasi ini diharapkan akan dirasakan oleh peserta didik terutama setelah mereka mengikuti program kegiatan pembelajaran. Penerapan metode partisipatorik diarahkan supaya peserta didik diharapkan melibatkan diri dalam ketiga tahapan pembelajaran itu.

Pemenggalan partisipasi peserta didik hanya dalam satu tahapan pembelajaran adalah metode yang menyimpang dari metode partisipatorik itu sendiri. Sebagai alasan dari penyimpangan tersebut karena metode partisipatorik menuntut terjadinya keikutsertaan peserta didik dalam pembelajaran. Realitas keikutsertaan itu dibuktikan dengan keaktifan peserta didik dalam perencanaan, pelaksanaan dan penilaian program pembelajaran. Dengan demikian, partisipasi peserta didik pada ketiga 
tahapan tersebut sangat diperlukan dalam penerapan metode partisipatorik dalam pembelajaran di kelas.

\section{METODE}

Penelitian ini merupakan jenis penelitian tindakan kelas. Tahapan-tahapan pelaksanaan tindakan dalam penelitian ini terdiri atas 4 tahapan. Adapun keempat tahapan tersebut antara lain: perencanaan (planning), tindakan (action), pengamatan (observation), dan refleksi (reflection). Selanjutnya keempat komponen tersebut dirangkaikan dalam suatu siklus kegiatan.

$$
\text { Penelitian ini menggunakan }
$$
variabel bebas yakni metode partisipatorik. Metode partisipatorik merupakan metode yang mengikutsertakan siswa dalam merencanakan, melaksanakan dan manilai kegiatan pembelajaran dalam mencapai tujuan pembelajaran. Dalam penerapan metode partisipatorik, guru hanya sebagai fasilitator dan siswalah yang lebih berpartisipasi penuh dalam pembelajaran.

Sumber data pada penelitian ini adalah siswa kelas VI SDN 146 Asaan Kabupaten Enrekang, sedangkan jenis data yang dikumpulkan ada 2, yaitu (1) lembar observasi dan (2) lembar pendapat siswa. Data tentang proses pembelajaran saat pelaksanaan tindakan diambil melalui lembar observasi.
Selanjutnya, peneliti mendeskripsikan tentang implementasi penerapan metode partisipatorik dalam pembelajaran tiap siklus yang masing-masing terdiri dari 2 (dua pertemuan. Data yang dideskripsikan adalah hasil observasi setiap pembelajaran dan lembar pendapat siswa, begitu pula dengan kritikan lisan dari siswa.

\section{HASIL DAN PEMBAHASAN}

Hasil penelitian dideskripsikan perpertemuan setiap siklus, yang mana dalam satu siklus terdiri dari 2 pertemuan. Tiap pertemuan dideskripsikan dengan empat klasifikasi, yakni perencanaan, pelaksanaan tindakan, observasi dan refleksi.

\section{Siklus I}

\section{Pertemuan Pertama}

Kegiatan observasi pada siklus I pertemuan pertama terlihat bahwa pada saat pembelajaran berlangsung, masih banyak siswa yang kurang memperhatikan pelajaran, mereka hanya mendiskusikan masalah lain. Hal ini terjadi karena tidak terpilihnya metode yang mereka ajukan. Masih banyak juga siswa yang tidak mencatat materi penting yang dijelaskan oleh gurunya. Menurut pengamatan peneliti, beberapa kelihatannya menulis, namun mereka hanya mengerjakan tugas mata pelajaran lain. Di samping itu, apabila siswa bekerja dalam kelompok 
terlihat kurang kerjasama antara anggotanya.

Di lain pihak, kehadiran siswa pada pertemuan pertama tidak dihadiri oleh 2 (dua) orang siswa. Hal ini dibuktikan dengan absensi kehadiran siswa. Dalam absen menunjukkan bahwa 2 (dua) orang siswa tidak hadir dan tidak diketahui penyebab ketidakhadiran mereka. Kemudian mengenai keaktifan siswa dalam memperhatikan penjelasan guru dan mencatat pelajaran yang dijelaskan kurang terkendali. Hal ini disebabkan oleh guru menerapkan metode pembelajaran berdasarkan hasil suara yang paling banyak, yakni metode diskusi, sehingga yang memilih metode lain kurang memperhatikan pelajaran. Akan tetapi, hanya sedikit yang tidak memilih metode diskusi sehingga hanya sedikit pula siswa yang kurang memperhatikan pembelajaran.

Keaktifan siswa menjawab pertanyaan guru dan mengajukan pertanyaan sangat minim. Hal ini disebabkan karena diperigaruhi oleh waktu yang digunakan dalam proses pembelajaran. Di samping itu, disebabkan pula oleh kurangnya motivasi dan guru sehingga spirit siswa untuk berkomentar sangat minim. Kemudian, guru juga terlalu membiarkan siswa yang cerdas mendominasi pembelajaran. Kesempatan berkomenta kebanyakan diberikan kepada siswa yang cerdas. Sangat jarang siswa pendiam diberikan kesempatan berkomentar.

\section{Pertemuan Kedua}

Dari kegiatan observasi pada siklus I pertemuan kedua terlihat bahwa perhatian siswa sudah mulai fokus saat pembelajaran berlangsung. Pada pertemuan kedua guru memilih metode dengan hasil suara yang paling sedikit, yakni pemecahan masalah. Meskipun demikian, siswa memperhatikan pembelajaran karena adanya pelibatan siswa terhadap pembelajaran. Akan tetapi, tidak bisa dipungkiri bahwa masih ada siswa yang mendiskusikan masalah lain pada saat guru memberikan materi. Kebanyakan mereka adalah siswa yang tidak terpilih metode yang diajukan. Ada juga yang terlihat mencatat materi pelajaran. Padahal, mereka tidak mencatat materi pelajaran melainkan hanya menulis materi yang lain.

Di lain pihak, kehadiran siswa pertemuan kedua menurun. Hal ini dibuktikan dengan absensi kehadiran siswa. Dalam absen menunjukkan bahwa 3 (tiga) orang siswa tidak hadir sedangkan pada hari pertama hanya dua orang siswa yang tidak hadir. Pada hari kedua tercatat 2 (dua) orang siswa sedang sakit dan 1 (satu) 
orang siswa tidak diketahui penyebab ketidakhadirannya.

Keaktifan siswa menjawab pertanyaan guru dan mengajukan pertanyaan mengalami penurunan. Hal ini juga disebabkan karena dipengaruhi oleh waktu yang digunakan dalam proses pembelajaran. Di samping itu, sama halnya dengan pertemuan pertama disebabkan pula oleh kurangnya motivasi dari guru sehingga spirit siswa untuk berkomentar sangat minim. Kemudian, guru juga terlalu membiarkan siswa yang cerdas mendominasi pembelajaran. Kesempatan berkomentar kebanyakan diberikan kepada siswa yang cerdas. Sangat jarang siswa pendiam diberikan kesempatan berkomentar.

Di samping itu, berdasarkan pengamatan peneliti diperoleh bahwa guru harus menyampaikan indikator materi secara sistematis, guru harus menambah suara pada saat mengajar, guru harus lebih memperhatikan siswa yang duduk di belakang dan yang kurang semangat dalam mengikuti pelajaran, guru harus memberi kesempatan kepada siswa untuk lebih berpartisipasi dalam pembelajaran. Perihal sama disampaikan oleh siswa pada saat guru memberikan kesempatan kepada siswa untuk menyampaikan penilaian mereka terhadap pembelajaran di kelas, begitu pula penampilan guru mereka. Penilaian disampaikan secara lisan dan secara tertulis. Penilaian tertulis dilakukan dengan mengisi lembar pendapat siswa yang dibuat oleh guru.

\section{Siklus II}

\section{Pertemuan Pertama}

Kegiatan observasi membuktikan bahwa perihal yang terjadi pada siklus I pertemuan pertama dan kedua tidak lagi terjadi pada siklus II pertemuan ketiga. Kehadiran siswa semakin meningkat. Hal itu dibuktikan dengan absensi siswa. Pada pertemuan ketiga ini hanya 1 (satu) orang siswa yang tidak hadir karena sakit. Hal itu disebabkan oleh adanya sanksi untuk siswa yang tidak hadir dan tidak ada pemberitahuan pada pertemuan pertama dan kedua pada siklus I. Sebagai sanksinya, guru mengembalikan kepada siswa. Siswa kebanyakan memberikan sanksi menyanyi atau membaca puisi. Sanksi seperti itu biasa juga diberikan oleh guru ketika ada siswa yang terlambat.

$$
\text { Keaktifan siswa dalam }
$$
pembelajaran juga semakin meningkat. Siswa aktif memperhatikan penjelasan guru. Mereka mencatat pelajaran yang penting pertemuan ketiga. Hal itu disebabkan oleh guru sering memeriksa catatan siswa pada akhir pembelajaran. Guru juga sering menegur siswa yang tidak 
mencatat. Teguran itu biasanya dengan bahasa halus, cerita sindiran, teguran langsung, memberikan pertanyaan, atau dengan cara lain.

Di lain pihak, dengan penerapan metode partisipatorik dalam pembelajaran siswa semakin berani menjawab pertanyaan guru dan temannya pada saat diskusi. Siswa juga semakin berani mengajukan pertanyaan. Hal ini disebabkan oleh guru sering memberikan penilaian kepada siswa yang sering bertanya dan menjawab pertanyaan.

Penerapan metode partisipatorik dapat meningkatkan intelektualitas dan emosionalitas siswa. Terbukti dengan sistematika penyampaian materi siswa pada saat presentase atau memberikan jawaban. Penalaran siswa semakin tertata dengan baik. Penggunaan bahasanya semakin terstruktur. Keberanian mengemukakan pendapat semakin tinggi. Apalagi memberikan pertanyaan setiap ada sesuatu yang belum dipahami oleh siswa.

Di samping itu, penerapan metode partisipatorik dapat meningkatkan kemampuan guru dalam mencerdaskan siswa. Banyak pengetahuan baru yang terkadang diperoleh oleh guru melalui partisipasi siswa. Terutama dalam hal diskusi, terkadang siswa menyampaikan argumen yang baru diketahui oleh guru.
Pengetahuan guru juga dipacu untuk bertambah luas karena siswa semakin berani bertanya setiap ada yang belum dipahami.

Dari beberapa masukan siswa tersebut, maka guru berusaha menerapkannya pada siklus II. Penerapan beberapa masukan siswa tersebut ternyata efektif. Terbukti, hubungan guru dengan siswa semakin akrab sehingga siswa semakin mudah dalam menerima pelajaran. Mereka tidak merasa enggan bertanya kalau ada materi yang belum dipahami, baik di dalam ruangan pada saat pembelajaran berlangsung maupun ketika berada di luar ruangan.

\section{Pertemuan Kedua}

Dari kegiatan observasi membuktikan bahwa yang terjadi pada siklus I tidak lagi terjadi pada siklus II. Kehadiran siswa semakin meningkat. Pada pertemuan ketiga hanya I (satu) orang siswa yang tidak hadir karena sakit. Kemudian pada pertemuan keempat siswa sudah hadir semua. Hal itu memang disebabkan oleh adanya sanksi untuk siswa yang tidak hadir dan tidak ada pemberitahuan. Perihal tersebut dibuktikan dengan komentar siswa pada saat guru bertanya kepada siswa terkait dengan peningkatan kehadiran siswa yang berbeda dengan hari sebelumnya. Siswa takut tidak 
hadir karena sanksinya ditentukan oleh siswa berhubung guru selalu mengembalikan kepada siswa tentang perihal sanksi yang diberikan kepada temannya. Siswa takut jangan sampai sanksinya tidak bernuansakan pendidikan. Siswa juga semakin rajin dan tidak lagi sering terlambat masuk di kelas pada saat pembelajaran akan dimulai. Perihal ini disebabkan guru memberikan sanksi yang sama dengan siswa yang tidak hadir apabila ada siswa yang terlambat.

Keaktifan siswa dalam pembelajaran juga semakin meningkat. Siswa aktif memperhatikan penjelasan guru. Mereka mencatat pelajaran yang penting pertemuan keempat. Hal itu juga disebabkan oleh guru sering memeriksa catatan siswa pada akhir pembelajaran. Guru juga sering menegur siswa yang tidak mencatat. Teguran itu biasanya dengan bahasa halus, cerita sindiran, teguran langsung, memberikan pertanyaan, atau dengan cara lain. Perihal ini dibuktikan dengan komentar siswa saat guru menanyakan perihal keaktifan siswa pada saat pembelajaran.

Di lain pihak, dengan penerapan metode partisipatorik dalam pembelajaran siswa semakin berani menjawab pertanyaan guru dan temannya pada saat diskusi. Siswa juga semakin berani mengajukan pertanyaan. Hal int disebabkan oleh guru sering memberikan penilaian kepada siswa yang sering bertanya dan menjawab pertanyaan. Di samping itu, guru juga mengkanter siswa yang sering mendominasi pembelajaran pada saat berdiskusi. Dalam hal ini guru meminta kepada siswa tersebut untuk memberikan kesempatan kepada temannya yang lain. Guru menggunakan pendekatan persuasif agar siswa tersebut tidak merasa tersisihkan.

Penerapan metode partisipatorik memang dapat meningkatkan intelektualitas dan emosionalitas siswa. Terbukti dengan sistematika penyampaian materi siswa pada saat presentase atau memberikan jawaban. Penalaran siswa semakin tertata dengan baik. Penggunaan bahasanya semakin terstruktur. Keberaian mengemukakan pendapat semakin tinggi. Apalagi memberikan pertanyaan setiap ada sesuatu yang belum dipahami oleh siswa. Perihal ini dibuktikan pada saat mereka diskusi pada pertemuan kedua siklus II. Siswa terlihat begitu antusias berdiskusi.

\section{PEMBAHASAN}

Dalam penerapan metode partisipatorik, ternyata guru mampu mengaktifkan siswa dalam pembelajaran. Hal ini dapat dilihat dari hasil observasi yang dilakukan selama pelaksanaan 
tindakan tiap siklus yang masing-masing terdiri dari 2 (dua) pertemuan yang telah dideskripsikan di atas. Sebagai buktinya yakni kehadiran siswa tiap pertemuan semakin meningkat, semakin banyak siswa yang bertanya, siswa semakin berani menjawab jika guru mengajukan pertanyaan, dan perhatian siswa terhadap materi pelajaran juga semakin meningkat.

Sebagian besar siswa mengatakan merasa tertarik dan senang belajar Bahasa Indonesia melalui metode partisipatorik. Alasannya, adanya hubungan keakraban antara siswa dengan siswa dan antara siswa dengan guru sehingga mereka merasa lebih mudah belajar dan berani mengungkapkan jawaban maupun idenya. Akhirnya, dengan ketertarikan siswa yang demikian, maka dengan sendirinya akan mendorong peningkatan aktivitas siswa dalam pembelajaran.

Meskipun demikian, metode partisipatorik bukanlah satu-satunya metode terbaik yang dapat digunakan dalam pembelajaran Bahasa Indonesia, melainkan metode tersebut dapat dijadikan bahan pertimbangan sebagai salah satu alternatif metode yang dapat digunakan dalam pembelajaran Bahasa Indonesia. Pada dasarnya, setiap metode lahir hanya untuk menutupi kekurangan metode sebelumnya. Dengan demikian, setiap metode pada hakikinya hanya saling melengkapi. Untuk itu, guru harus mahir memadukan berbagai macam metode.

\section{SIMPULAN}

Berdasarkan hasil penelitian dan pembahasan yang diperoleh, maka dapat disimpulkan antara lain: (1) Penerapan metode partisipatorik terhadap pembelajaran Bahasa Indonesia dapat mengaktifkan siswa dalam pembelajaran sehingga kecerdasan intelektual dan kecerdasan emosional siswa semakin meningkat; dan (2) Partisipasi siswa yang dapat dikembangkan oleh guru diantaranya menentukan dan menyiapkan alat dan bahan yang digunakan dalam kegiatan pembelajaran, melibatkan siswa dalam memilih metode pembelajaran, dan menilai pelaksanaan proses pembelajaran.

\section{DAFTAR PUSTAKA}

Arikunto, Suharsimi. 2001. Dasar-Dasar Evaluasi Pendidikan (Edisi Revisi). Jakarta: Bumi Aksara.

Djumingun, Sulastriningsih. 2007. Strategi Belajar-Mengajar Bahasa dan Sastra Indonesia serta Penerapannya. Makassar: Badan Penerbit UNM.

Hamalik, Oemar. 2002. Pendidikan Guru Berdasarkan Pendekatan Kompetensi. Jakarta: Bumi Aksara.

Hasibuan, JJ., dkk. 1985. Proses Belajar Mengajar. Bandung: Rosdakarya. 
Mahsun. 2005. Metode Penelitian Bahasa:

Tahapan Strategi, Metode, dan

Tekniknya. Jakarta: PT. Raja

Grafindo Persada.

Sabri, Ahmad. 2007. Strategi Belajar Mengajar dan Micro Teaching. Padang: Quantum Teaching.

Sagala, S. 2005. Konsep dan Makna Pembelajaran. Bandung: Alfabeta.

Sudjana, S. 2005. Metode dan Teknik Pembelajaran Partisipatif. Bandung: Falah Production. 